\title{
Factors Influencing the Success of Communities of Practice in the Interior Decoration Industry
}

\author{
Hao-Cheng Huang ${ }^{1, *}$, Yeng-Horng Perng ${ }^{2}$ \\ Department of Architecture \\ National Taiwan University of Science and Technology \\ Taipei, Taiwan \\ ${ }^{1}$ E-mail: lifu168design@yahoo.com.tw \\ Tel.: +886-9-33294668; Fax: +886-7-2816966 \\ ${ }^{2}$ E-mail: perng@mail.ntust.edu.tw \\ Corresponding author.
}

\begin{abstract}
Knowledge management and the accumulation of knowledge assets can enhance an enterprise's competitiveness. However, knowledge is intangible and immeasurable, and effective knsawledge management is challenging. The interior decoration industry is characterized by project implementation and discontinuous management and therefore cannot easily manage knowledge assets. Therefore, we propose communities of practice as a model to help introduce the construction industry into the field of knowledge management. We explain how this can help interior decoration firms improve knowledge management, collect tangible and intangible knowledge, accumulate intangible assets, achieve sustainable development, and enhance competitiveness. Moreover, we adopted the Delphi method and analytical hierarchy process to explore factors that would influence the success of communities of practice in the interior decoration industry.
\end{abstract}

Keywords-Knowledge management; community of practice; interior decoration firm; Delphi method; analytical hierarchy process

\section{IINTRODUCTION}

Big Data has become a crucial knowledge asset for business management, and community of practice is an effective strategy by which enterprises can construct knowledge assets. Community of practice can be used to understand overall market development tendencies and customers' preferences through opinion exchange, communication, coordination, and interactions among people. For the interior decoration industry, community of practice includes the following functions: interaction, communication, problem handling, problem solving, building consensus, and long-term cooperation. In addition, community of practice can connect business owners, customers, interior designers, construction teams, and material suppliers to efficiently handle procurement and contracting, as well as issues of design illustration and regulations, to enhance management effectiveness, reduce costs, control work progress, and assure work quality. Community of practice can integrate interfaces and apply, share, and accumulate knowledge. Fig. 1 shows a community of practice framework for the interior decoration industry.

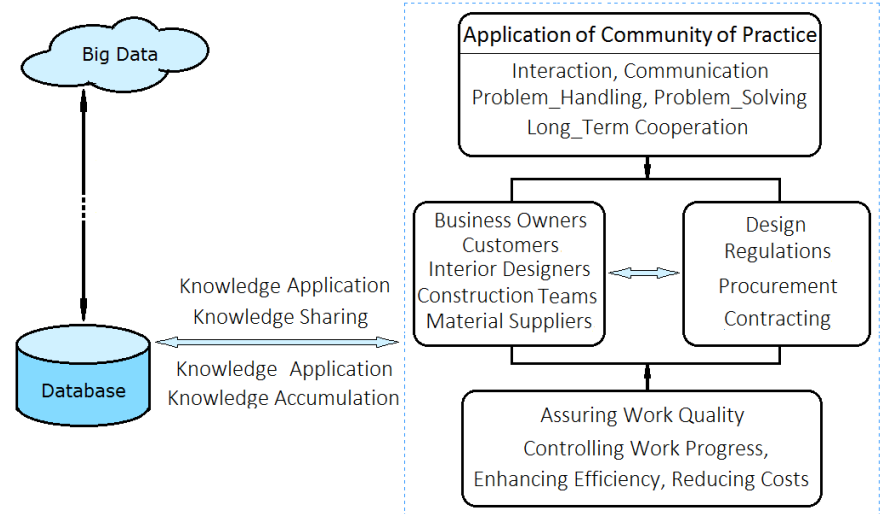

Fig. 1. Development and application of community of practice for the interior decoration industry

The construction industry plays a crucial role in both developing and developed countries [1] and has contributed to overall economic development, accounting for over $10 \%$ of gross domestic product in many developing countries [2]. The development of the construction industry can be a crucial economic indicator for national development, and governments are major clients [3]. The Taiwanese government has endeavored to reform the construction industry in Taiwan to enhance its global competiveness, and has considered the construction community of practice as a crucial project for national development. The main purpose is to improve the competitiveness and efficiency of the Taiwanese construction industry and to enhance overall national competitiveness. Because interior decoration companies are part of the supply chain of the construction industry, introducing them into community of practice helps with accumulating tangible and intangible knowledge, building knowledge assets for the companies, and improving corporate competitiveness.

Community of practice is a novel method for managing the traditional interior decoration industry and introducing Internet technology to it. Knowledge management can influence overall organizational development; in particular, the management and innovation of an enterprise information system [4,5] can help enterprises improve their core competitiveness. However, most interior decoration business owners do not understand the concept of community of 
practice. The interior decoration industry is not as familiar with knowledge management and the community of practice as the technology industry, perhaps because the interior decoration industry has been focused on tangible construction management for a long period. In addition, the portfolio of community of practice and knowledge domains is determined by its importance to the effectiveness of business operations, and whether the knowledge is widely known or bound to a smaller group of professional experts [6]. A community of practice can help preserve and apply knowledge, as people can learn techniques from experts and jointly solve problems online.

In this study, we applied the concept of community of practice to collect intangible knowledge assets and explore the factors that influence the success of an interior decoration firm, as well as help introduce the interior decoration industry into the field of knowledge management.

\section{LITERATURE REVIEW}

Knowledge management can improve a firm's management performance. According to Wenger and Snyder, community of practice is a method for managing knowledge and building a firm's core competitiveness [7]. A community of practice typically uses common training methods and similar work activities and tools to share experience and value [8]. Lesser and Storck considered that a community of practice involves community members who have common interests and goals [9], and often share opinions and information and learn from one another. A community of practice can enhance implementation efficiency through online group meetings, opinion exchange, and problem solving.

Corporate knowledge management comprises various development processes and stages (e.g., the knowledgechaotic, knowledge-aware, knowledge-enabled, and knowledge-managed stages) [10,11]. The knowledge-chaotic stage is the most basic and challenging, in which knowledge is intangible and cannot be measured or effectively managed with a conventional management model. In addition, how to retrieve and integrate knowledge during a chaotic period is challenging because explicit and implicit knowledge are mixed and stored in employees, corporate manufacturing processes, archives, and partners [12]. A community of practice is a basic means of organizing knowledge and a crucial operating unit for promoting knowledge management [13]. A community of practice can effectively accumulate, share, and apply knowledge; for example, IBM founded a community of practice in which employees successfully shared their stories, reduced costs, and enhanced revenues and profits [14]. Successfully founding a community of practice requires a valid process. Gongle and Rizzuto investigated how IBM developed a community of practice in 1995 and found that its development comprised five stages [14]: potential, establishment, fit, active, and support. These stages were core elements for its successful development. At the potential stage, the community of practice began to form and effectively manage knowledge during a chaotic period.

In recent years, technology has developed rapidly and Big Data has increased competition among enterprises; in addition, the Taiwanese government has endeavored to reduce bid rigging in the construction industry. The Taiwanese government has also enacted the Government Procurement Act to regulate public construction contracts fairly and openly. Moreover, the Construction and Planning Agency promoted the 2008 e-Taiwan challenge project and specifically budgeted for implementing knowledge management in the Taiwanese construction industry to improve its competitiveness and culture. Because a community of practice is a basic unit for promoting knowledge management [8], a community of practice can be a crucial strategy for implementing knowledge management. In the 2008 e-Taiwan challenge project, the Taiwanese government considered building a community of practice for the construction industry as a national development strategy for introducing knowledge management into the construction industry. In the interior decoration industry, a platform for the community of practice in the construction industry can be established to comply with the national development plan and enhance the competitiveness of the construction industry as a whole.

Numerous factors have influenced the success in developing a community of practice for the interior decoration industry (e.g., internal procedures for each firm, customer responses, financial situations, and innovation and learning issues). In this study, we summarized the following factors, which are common management issues for interior decoration firms: whether a firm creates an environment that encourages employees to interact and share knowledge, whether a firm continues to seek new knowledge, whether executives support knowledge management and invite experts to teach new ideas, whether an innovative reward system is established, whether regular meetings are held to review experimental results and share ongoing projects, whether innovation policies are implemented, how customer complaints are handled, how work delays are handled, and how work progress is managed.

\section{METHODS AND RESEARCH DESIGN}

In this study, we adopted the Delphi method and analytical hierarchy process (AHP) to explore factors that influence the success in developing a community of practice for the interior decoration industry. The content, as well as the two research methods and their designs, are described in the following sections.

\section{A. Delphi Method and Research Design}

The Delphi method is an effective methodology related to group decision making. In addition, the Delphi method is an interactive method in which independent experts exchange opinions regarding the development and management of an enterprise, which is not limited to the prediction of future events [15]. In the Delphi method, industry insiders, government officials, and scholars with more than 10 years of working experience in related fields are first invited to serve as experts. Preliminary factors are identified from previous studies or other data, and these factors become the basis for designing the first Delphi questionnaire. This questionnaire can be administered face-to-face or through the mail, although it must be conducted repeatedly until a consensus is achieved. Fig. 2 illustrates the entire Delphi procedure. 


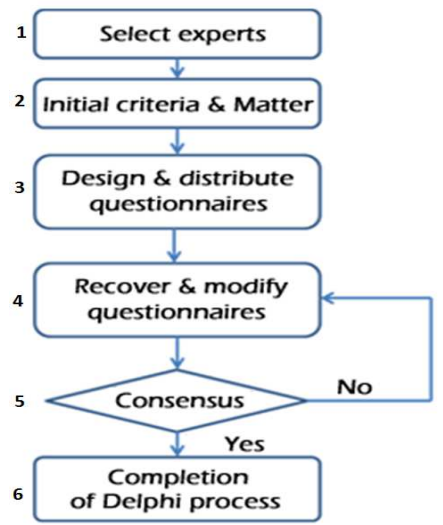

Fig. 2. Delphi method procedure

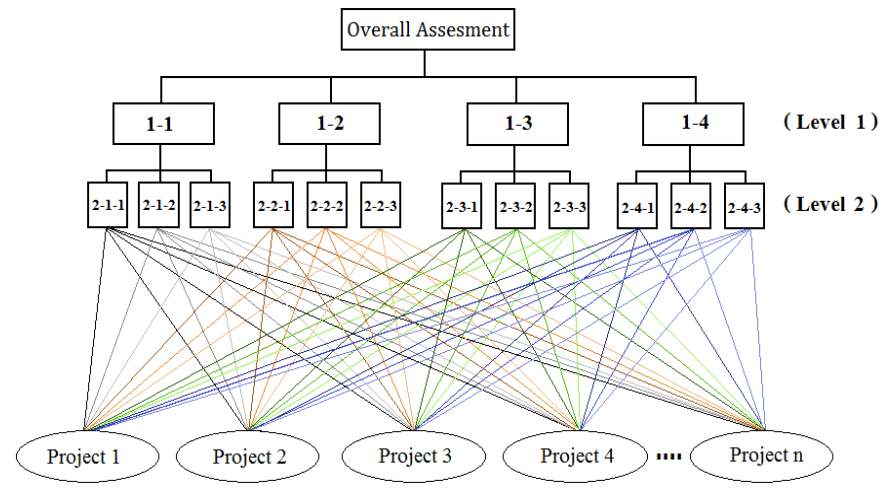

Fig. 3. Hierarchical framework of influential factors for communities of practice in the interior decoration industry

According to Hsueh, the procedures for the Delphi questionnaire survey comprise the following six steps [16]:

1) Selecting experts (industry insiders, government officials, and scholars);

2) Identifying preliminary factors;

3) Designing and distributing Delphi questionnaires;

4) Achieving a consensus among experts;

5) Repeating Steps 3 and 4 if a consensus is not achieved;

6) Ending the procedure after a consensus is achieved.

Overall, 10 participants (4 industry managers, 3 government officials, and 3 scholars) participated in this study. The Delphi questionnaire was conducted by recording interviews and mailing questionnaires to participants, most of whom were corporate employees who actively promoted knowledge management according to government policies. The participants had experience in operating a community and could therefore provide representative views about how to operate one. From March 2017 to May 2017, two rounds of Delphi questionnaires were conducted and a consensus was achieved. Table 2 shows the preliminary and confirmed dimensions, as well as the factors influencing a community of practice in the interior decoration industry according to the Delphi results.
TABLE I. DIMENSIONS AND FACTORS INFLUENCING A COMMUNITY OF PRACTICE IN THE INTERIOR DECORATION INDUSTRY

\begin{tabular}{|c|c|c|}
\hline $\begin{array}{l}\text { Preliminary } \\
\text { Dimensions }\end{array}$ & $\begin{array}{l}\text { Confirmed } \\
\text { Dimensions } \\
\end{array}$ & Influential Factors \\
\hline \multirow{3}{*}{$\begin{array}{l}\text { Customer } \\
\text { responses }\end{array}$} & \multirow{3}{*}{$\begin{array}{l}\text { Customer } \\
\text { services (1-1) }\end{array}$} & Work progress (2-1-1) \\
\hline & & Work quality (2-1-2) \\
\hline & & Maintenance and services (2-1-3) \\
\hline \multirow{3}{*}{$\begin{array}{l}\text { Financial } \\
\text { perspective }\end{array}$} & \multirow{3}{*}{$\begin{array}{l}\text { Competitiveness } \\
(1-2)\end{array}$} & $\begin{array}{l}\text { Project implementation performance (2-2- } \\
1)\end{array}$ \\
\hline & & $\begin{array}{l}\text { Community investment effectiveness (2-2- } \\
\text { 2) }\end{array}$ \\
\hline & & Project profitability (2-2-3) \\
\hline \multirow{3}{*}{$\begin{array}{l}\text { Internal } \\
\text { procedure } \\
\text { perspective }\end{array}$} & \multirow{3}{*}{$\begin{array}{l}\text { Management of } \\
\text { internal } \\
\text { procedures (1-3) }\end{array}$} & Shortening operation procedures (2-3-1) \\
\hline & & \begin{tabular}{|l|} 
Number of friends $(2-3-2)$ \\
\end{tabular} \\
\hline & & Interaction between employees (2-3-3) \\
\hline \multirow{3}{*}{$\begin{array}{l}\text { Innovation and } \\
\text { learning } \\
\text { perspective }\end{array}$} & \multirow{3}{*}{\begin{tabular}{|l} 
Innovative \\
education and \\
training (1-4)
\end{tabular}} & Immediate training effectiveness (2-4-1) \\
\hline & & Knowledge preservation and reuse (2-4-2) \\
\hline & & Employee participation level (2-4-3) \\
\hline
\end{tabular}

\section{B. Analytical Hierarchy Process and Research Design}

Saaty first proposed the AHP method to solve multiattribute decision-making problems [17]. A hierarchical framework of influential factors must first be determined and then an AHP questionnaire is designed, which can be used to compare any pair of influential factors at various hierarchical levels and to calculate their relative weightings according to the AHP formula. This formula can also test the consistency of the relative weightings. According to Saaty and Vargas, the AHP method is applicable for setting priorities [18], generating a set of alternatives, selecting the best option, determining requirements, allocating resources, predicting outcomes, measuring performance, designing systems, insuring system stability, optimization, planning, and resolving conflict and risk assessments.

Fig. 3 shows the multiattribute hierarchical framework established through AHP according to the dimensions and factors (Table 1) involved in communities of practice in the interior decoration industry. The relative weightings of these influential factors can also be used to assess said communities of practice.

\section{WEIGHTINGS AND RANKING OF INFLUENTIAL FACTORS}

The hierarchical framework (Fig. 3) was the basis for designing an AHP questionnaire to compare any pair of influential factors at each hierarchical level. Subsequently, the AHP equation is used to obtain the relative weightings of the criteria. Returned AHP questionnaires must meet the requirements of the consistency test to be regarded as valid (consistency index $[\mathrm{CI}] \leq 1$; consistency ratio $[\mathrm{CR}] \leq 0.1$ ).

In this study, 80 AHP questionnaires were distributed and 48 valid responses were returned. The mean of all valid questionnaires was used to calculate the relative weightings of various factors that influence communities of practice in the interior decoration industry. Tables 2-6 show the relative weightings of influential dimensions at the first hierarchical level and influential factors at the second hierarchical level. Table 7 presents the relative weightings and the ranking of various factors that influence communities of practice in the interior decoration industry. 
Table 7 presents the weight values (wi) of various factors that influence communities of practice in the interior decoration industry. In descending order of importance, these factors are knowledge preservation and reuse (2-4-2), maintenance and services (2-1-3), project profitability (2-2-3), number of friends (2-4-3), and employee participation level (2-4-3). According to the ranking analysis, innovative education and training is the most crucial for introducing communities of practice into the interior decoration industry. Knowledge preservation and reuse would help the traditional industry build knowledge assets, satisfy customers with maintenance services, and enhance project profitability. Moreover, the community of practice should emphasize the importance of employee participation to improve overall effectiveness.

TABLE II. COMPARISON MATRIX OF THE EVALUATION ELEMENTS FOR INFLUENTIAL FACTORS AT THE FIRST HIERARCHICAL LEVEL

\begin{tabular}{|c|c|c|c|c|}
\hline \multicolumn{5}{|c|}{$\begin{array}{l}\text { Comparison of (1-1), (1-2), (1-3) and (1-4) in their influence to overall } \\
\text { assessment }\end{array}$} \\
\hline Attributes & $(1-1)$ & $(1-2)$ & $(1-3)$ & $(1-4)$ \\
\hline$(1-1)$ & 1 & 1.321 & 0.643 & 1.233 \\
\hline$(1-2)$ & 0.757 & 1 & 1.121 & 0.704 \\
\hline$(1-3)$ & 0.643 & 0.892 & 1 & 0.264 \\
\hline$(1-4)$ & 0.811 & 1.420 & 3.787 & 1 \\
\hline eigenvector & 0.26 & 0.22 & 0.16 & 0.37 \\
\hline
\end{tabular}

\section{TABLE III. COMPARISON MATRIX OF THE EVALUATION ELEMENTS FOR} INFLUENTIAL FACTORS AT HIERARCHY LEVEL 2-1

\begin{tabular}{|c|c|c|c|}
\hline \multicolumn{4}{|c|}{$\begin{array}{l}\text { Comparison of (2-1-1), (2-1-2), and (2-1-3) in their influence to overall } \\
\text { assessment }\end{array}$} \\
\hline Attributes & $(2-1-1)$ & $(2-1-2)$ & $(2-1-3)$ \\
\hline$(2-1-1)$ & 1 & $1 / 2$ & $1 / 5$ \\
\hline$(2-1-2)$ & 2 & 1 & $1 / 2$ \\
\hline$(2-1-3)$ & 5 & 2 & 1 \\
\hline eigenvector & 0.13 & 0.28 & 0.59 \\
\hline \multicolumn{4}{|c|}{ C.R. $=0.03337$, R.I. $=0.58, \mathrm{CI}=0.01936$} \\
\hline
\end{tabular}

TABLE IV. COMPARISON MATRIX OF THE EVALUATION ELEMENTS FOR INFLUENTIAL FACTORS AT HIERARCHY LEVEL 2-2

\begin{tabular}{|c|c|c|c|}
\hline \multicolumn{4}{|c|}{$\begin{array}{l}\text { Comparison of }(2-2-1),(2-2-2) \text { and }(2-2-3) \text { in their influence to overall } \\
\text { assessment }\end{array}$} \\
\hline Attributes & $(2-2-1)$ & $(2-2-2)$ & $(2-2-3)$ \\
\hline$(2-2-1)$ & 1 & 3 & $1 / 3$ \\
\hline$(2-2-2)$ & $1 / 3$ & 1 & $1 / 5$ \\
\hline$(2-2-3)$ & 3 & 5 & 1 \\
\hline eigenvector & 0.26 & 0.11 & 0.63 \\
\hline \multicolumn{4}{|c|}{ C.R. $=0.00477$ R.I. $=0.58, \mathrm{CI}=0.00277$} \\
\hline
\end{tabular}

TABLE V. COMPARISON MATRIX OF THE EVALUATION ELEMENTS FOR INFLUENTIAL FACTORS AT HIERARCHY LEVEL 2-3

\begin{tabular}{|c|c|c|c|}
\hline \multicolumn{4}{|c|}{$\begin{array}{l}\text { Comparison of }(2-3-1),(2-3-2) \text { and }(2-3-3) \text { in their influence to overall } \\
\text { assessment }\end{array}$} \\
\hline Attributes & $(2-3-1)$ & $(2-3-2)$ & $(2-3-3)$ \\
\hline$(2-3-1)$ & 1 & $1 / 3$ & 1 \\
\hline$(2-3-2)$ & 3 & 1 & 3 \\
\hline$(2-3-3)$ & 1 & $1 / 3$ & 1 \\
\hline eigenvector & 0.2 & 0.6 & 0.2 \\
\hline \multicolumn{4}{|c|}{ C.R. $=0$, R.I. $=0.58, \mathrm{CI}=0$} \\
\hline
\end{tabular}

TABLE VI. COMPARISON MATRIX OF THE EVALUATION ELEMENTS FOR INFLUENTIAL FACTORS AT HIERARCHY LEVEL 2-4

\begin{tabular}{|c|c|c|c|}
\hline \multicolumn{4}{|c|}{$\begin{array}{l}\text { Comparison of }(2-4-1),(2-4-2) \text { and }(2-4-3) \text { in their influence to overal } \\
\text { assessment }\end{array}$} \\
\hline Attributes & $(2-4-1)$ & $(2-4-2)$ & $(2-4-3)$ \\
\hline$(2-4-1)$ & 1 & $1 / 4$ & $3 / 4$ \\
\hline$(2-4-2)$ & 4 & 1 & $2(1 / 2)$ \\
\hline$(2-4-3)$ & $1(1 / 3)$ & $2 / 5$ & 1 \\
\hline eigenvector & 0.16 & 0.61 & 0.23 \\
\hline \multicolumn{4}{|c|}{ C.R. $=0.00319$ R.I $=0.58, \mathrm{CI}=0.0185$} \\
\hline
\end{tabular}

TABLE VII. WEIGHT VALUES (WI) OF VARIOUS FACTORS INFLUENCING COMMUNITIES OF PRACTICE IN THE INTERIOR DECORATION INDUSTRY

\begin{tabular}{|c|c|c|c|c|c|}
\hline $\begin{array}{l}\text { Influential } \\
\text { dimensions }\end{array}$ & $\begin{array}{l}\text { Level } \\
\text { 1(wi) }\end{array}$ & \begin{tabular}{|l|} 
Influential \\
factors
\end{tabular} & $\begin{array}{l}\text { Level } \\
\text { 2(wi) }\end{array}$ & $\begin{array}{l}\text { Criteria } \\
\text { (wi) }\end{array}$ & Ranking \\
\hline \multirow{3}{*}{$\begin{array}{l}\text { Customer services } \\
(1-1)\end{array}$} & \multirow[t]{3}{*}{0.26} & $(2-1-1)$ & 0.13 & 0.0338 & 9 \\
\hline & & $(2-1-2)$ & 0.28 & 0.0728 & 6 \\
\hline & & $(2-1-3)$ & 0.59 & 0.1534 & 2 \\
\hline \multirow{3}{*}{$\begin{array}{l}\text { Competitiveness } \\
(1-2)\end{array}$} & \multirow[t]{3}{*}{0.22} & $(2-2-1)$ & 0.26 & 0.0572 & 8 \\
\hline & & $(2-2-2)$ & 0.11 & 0.0242 & 11 \\
\hline & & $(2-2-3)$ & 0.63 & 0.1386 & 3 \\
\hline \multirow{3}{*}{$\begin{array}{l}\text { Management of } \\
\text { internal procedures } \\
(1-3)\end{array}$} & \multirow[t]{3}{*}{0.16} & $(2-3-1)$ & 0.20 & 0.032 & 10 \\
\hline & & $(2-3-2)$ & 0.60 & 0.096 & 4 \\
\hline & & $(2-3-3)$ & 0.20 & 0.032 & 10 \\
\hline \multirow{3}{*}{$\begin{array}{l}\text { Innovative education } \\
\text { and training } \\
(1-4)\end{array}$} & \multirow[t]{3}{*}{0.37} & $(2-4-1)$ & 0.16 & 0.0592 & 7 \\
\hline & & $(2-4-2)$ & 0.61 & 0.2257 & 1 \\
\hline & & $(2-4-3)$ & 0.23 & 0.0851 & 5 \\
\hline \multicolumn{4}{|c|}{ Overall Weight value(wi) } & \multicolumn{2}{|l|}{1.01} \\
\hline
\end{tabular}

\section{CONCLUSION}

The construction of a knowledge community is a key development strategy for enhancing the competitiveness of the supply chain of the construction industry in Taiwan. This strategy introduces knowledge management, helping an industry that has long paid attention to tangible assets to learn how to collect knowledge through member interactions and how to repeatedly use, share, and benefit from such intangible assets. Because a community of practice can create a stressfree interactive communication environment, the construction industry can build excellent relationships with upstream and downstream supply chains through mutual understanding; accordingly, the construction industry can reduce losses caused by poor communication, prevent the occurrence of conflicts, and enhance work effectiveness and efficiency.

Although the interior decoration industry is part of the supply chain of the construction industry, it has a much smaller scale. In addition, because of its low technical threshold, low capital required, techniques that cannot be easily improved, and the multitude of existing firms, competition in this industry can be vicious. If the interior decoration industry can build a platform for a community of practice to improve companies' knowledge management and to reuse knowledge assets, the industry can enhance efficiency, reduce costs, improve its corporate culture, and enhance robustness by sharing, applying, and creating knowledge.

According to the results of this study, the factors influencing the success of communities of practice in the interior decoration industry are as follows: knowledge preservation and reuse, maintenance and services, project profitability, the number of friends, and employee 
participation level. Given these factors, we propose the following suggestions.

1) An interior decoration firm typically employs only a few employees (approximately 20 to 30; fewer than 10 in some firms). A community of practice can still be introduced into these firms. Decision-makers should encourage employees to participate in the community of practice to enhance work efficiency and to solve problems related to staff shortages.

2) A community of practice can help firms deploy or subcontract their work, and helps material suppliers supply materials in a timely fashion, thereby enhancing project effectiveness.

3) A community of practice can help small-scale firms or firms with staff shortage issues to manage project archives and intangible knowledge assets through database management.

4) The introduction of communities of practice into the interior decoration industry can encourage employees to participate, learn, and manage new knowledge, thus improving professional skills and experiences.

5) More effective maintenance and services helps increase the number of friends and improves advertising effectiveness, as well as enhancing a firm's visibility, profitability, and robustness.

\section{References}

[1] J. Lopes, L. Ruddock, and F.L. Ribeiro, "Investment in construction and economic growth in developing countries," Build. Res. Inf., vol. 30, pp. 152-159, 2002.

[2] D. Crosthwaite, "The global construction market: a cross-sectional analysis," Constr. Manage. Econ., vol. 18, pp. 619-627, 2000.

[3] G. Seaden and A. Manseau, "Public policy and construction innovation," Build. Res. Inf., vol. 29, pp. 182-196, 2001.
[4] R. Arora, "Implementing KM-a balanced score card approach," J. Knowl. Manag., vol. 6, pp. 240-249, 2002.

[5] J. de Gooijer, "Designing a knowledge management performance framework," J. Knowl. Manag., vol. 4, pp. 303-310, 2000.

[6] G.V. Krogh, I. Nonaka, and M. Aben, "Making the most of your company's knowledge: a strategic framework," Long Range Plann., vol. 34, pp. 421-439, 2001.

[7] E. Wenger and W.M. Snyder, Cultivating Communities of Practice, Boston: Haven Business School Press, 2001.

[8] D.R. Millen, M.A. Fontaine, and M.J. Muller, "Understanding the benefit and cost of communities of practice," Commun. Acm, vol. 45 , issue, pp. 69-73, 2002.

[9] E.L. Lesser and J. Storck, "Communities of practice and organizational performance," IBM Syst. J., vol. 40, pp. 831-841, 2001.

[10] D. Parlby, Knowledge Management Research Report 1988, London: KPMG Consulting, 1998.

[11] D. Parlby, Knowledge Management Research Report 2000, London: KPMG Consulting, 2000.

[12] Wikipedia, Knowledge management, https://zh.wikipedia.org/wiki/\%E7\%9F\%A5\%E8\%AF\%86\%E7\%AE\% A1\%E7\%90\%86 (retrieved on 2017/03/31)

[13] J.S. Brown and P. Duguid, "Organizational learning and communitiesof-practice: toward a unified view of working, learning and innovation," Organ. Sci., vol. 2, pp. 40-57, 1991.

[14] P. Gongla and C.R. Rizzuto, "Evolving communities if practice: IBM global services experience,” IBM Syst. J., vol. 40, pp. 842-862, 2001.

[15] E. Ziglio and M. Adler, Gazing into the Oracle: The Delphi Method and its Application to Social Policy and Public Health. London: Jessica Kingsley, pp. 1-33, 1996.

[16] S.L. Hsueh, "Assessing the effectiveness of community-promoted environmental protection policy by using a Delphi-fuzzy method: a case study on solar power and plain afforestation in Taiwan," Renew. Sust. Energ. Rev., vol. 49, pp. 1286-1295, 2015.

[17] T.L. Saaty, "How to make a decision: the analytic hierarchy process," Eur. J. Oper. Res., vol. 48, pp. 9-26, 1990.

[18] T.L. Saaty and L.G. Vargas, Prediction, Projection and Forecasting, Boston, MA: Kluwer Academic Publishers, 1991. 